\title{
Exploration and Practice of Applied Undergraduate Talents Cultivation in Electrical Engineering and Automation
}

\author{
Jingfeng $\mathrm{He}$ \\ School of Science, Xijing University \\ Xi'an, Shanxi, China \\ 573825625@qq.com
}

\begin{abstract}
This paper introduces the cultivation of applied undergraduate talents in electrical engineering and automation. From the definition of professional positioning, this paper provides to formulate training objectives and training plans, deepen teaching reform, improve teaching quality, and strengthen students' ability development. At last, extensive and in-depth exploration and exploration practice has achieved good results.
\end{abstract}

Keywords-Applied talents; Undergraduate teaching reform; Ability cultivation

\section{INTRODUCTION}

The electrical engineering and automation profession has trained a large number of senior technical talents for local industries, especially the power sector, most of the graduates have become technical backbones or responsible persons in various local industries, and have made certain contributions to local economic or regional economic development. contribution. Therefore, the electrical engineering and automation professions are favored, the students are sufficient, and the employment situation is good, especially the power system and automation direction of the profession. However, with the progress of social economy and technology and the vigorous development of higher education, On the one hand, many colleges and universities have expanded the enrollment scale of electrical engineering and automation; on the other hand, some universities are also opening electrical engineering and automation. Schools with electrical engineering and automation have also added power systems and their automation, In addition, in the face of the impact of the economic crisis, employment pressure is growing. Therefore, electrical engineering and its automation profession are facing the challenges and opportunities of the times. The more the school-running situation is, the more it is necessary to estimate the fierce competition, the more urgency. How to reform the talent training model in response to the needs of the $21 \mathrm{st}$ century, improve the quality of personnel training, enrich and expand the professional connotation, enhance the adaptability of graduates and improve the quality of teaching, improve the quality of running a school and develop your own professional characteristics, cultivate new types of electrical engineering and automation professionals at the grassroots level, it is a problem that needs to be studied and explored.
II. SCIENTIFIC ORIENTATION IS THE KEY TO DETERMINING THE APPLICATION GOAL OF ELECTRICAL ENGINEERING AND ITS

\section{AUTOMATION PROFESSIONAL APPLICATION TALENTS}

The scientific orientation of the application of talents in electrical engineering and automation is the key factor in determining the quality of personnel training. In the construction of electrical engineering and automation, In line with the idea of "taking students as the foundation, teachers as the leading force, teaching as the center, quality as the aim, the market as the guide, and the place as the basis, we can cultivate the high-level technical talents of the basic level who are able to live steadily and do well at the grass-roots level". Further strengthen the research and practice of the training mode of electrical engineering and automation professionals, strengthening course system construction and reform, pay attention to the cultivation of students' practice and innovation ability to ensure the teaching quality. Strengthening cooperation between schools and enterprises to improve the level of teaching and scientific research, to raise funds for running a school through various channels, continue to improve teaching facilities and strengthen the construction of teaching management system, strengthen the construction of teachers, improve the level of professional education, professional characteristics.

\section{A. Professional training objectives}

This major cultivates the needs of socialist modernization construction in the 21 st century, the moral [1], intellectual and physical development is comprehensive, the comprehensive quality is high, the application ability is strong, the foundation is solid, the knowledge is broad, and the strong electricity is the main, and the combination of strong and weak electricity. Students received basic training in electrical engineering, electrical and electronic technology, computer control technology, and control theory. To cultivate "grassroots application type" senior technical talents who can endure hardship, stay stable, work well, have strong entrepreneurial ability and high engineering quality in the industries of small and medium-sized hydropower plants, thermal power plants and county-level electric power companies. 


\section{B. Service oriented. Based on Shaanxi, service peripheral, radiation all over the country}

The graduates mainly serve the economic development of the electric power industry and the automation technology industry of industrial and mining enterprises in the northwest region and shaanxi region, and radiate to the national electric power industry and other fields [2].

\section{Professional development direction and characteristics}

This major is divided into three professional directions (power system and its automation, industrial automation, transmission line engineering design). The first two years were implemented as general knowledge education. At the end of the second semester of sophomore year, students chose a direction to learn professional skills according to the needs of the social talent market and their personal specialties. Adopt the mode of "characteristic education specialty education". Special education: Teach students according to their aptitude and implement the tutorial system. According to the students' special characteristics and hobbies, starting from freshmen, we should select and train talents with special expertise in the following three aspects.

First, cultivate about $15 \%$ of the academic talents who can be admitted to graduate students; Second, training about $5 \%$ of business management talents with leadership skills; Third, cultivate about $5 \%$ of innovative, entrepreneurial ability of innovative talent. The tutorial system is to cultivate students' scientific research ability under the guidance of tutors according to their scientific research direction and students' special strength and interest, from the end of the second semester of sophomore year to carry on the two-way selection, under the guidance of the tutors, to cultivate the students' scientific research ability. Professional education: According to the professional orientation and training goal, we can train the advanced applied technical talents of electrical engineering base level who can work well and endure hardships.

\section{THE COURSE SYSTEM CONSTRUCTION OF THE TRAINING MODE OF ELECTRICAL ENGINEERING SPECIALTY}

It is the core of achieving the goal of training and improving the quality of talents. It should meet the requirements of training goals and specifications. Constructing the new education mode of "knowledge and ability" parallel, optimizing the course structure system, organizing the teaching content rationally, In terms of training goal, the project features of technology application and technology development should be emphasized, and the training of talents should be oriented to serve the local enterprises directly and the local economy [3].

According to the course function, it is divided into public basic curriculum group, professional technology curriculum group and practice curriculum group. When revising the 2018 undergraduate talent training program, we followed education teaching rules, constantly changed and updated education teaching concepts, correctly handled the relationship between political ideology and moral character and professional knowledge, theory and practice, knowledge and ability, teaching and self-study, and paid attention to coordination and unification. Further optimize and integrate the course structure system. Pay attention to the intersection of disciplines, infiltration of arts and sciences, and the combination of science and engineering; pay attention to the relationship between basic courses, professional courses, elective courses and practical teaching. Deepening the curriculum reform and establishing the corresponding experimental curriculum system. Gradually form a scientific, reasonable curriculum system [4].

The courses set according to the curriculum system should follow the teaching rules and pay attention to the mutual connection, cooperation and infiltration.

In order to arouse students' enthusiasm in learning, a certain number of elective courses are set so that students have the opportunity to choose learning contents and build knowledge by themselves, have some time for self-study, develop personal interests and hobbies and abilities, give full play to students' talents and potential, and improve learning results.

The public basic course group consists of a series of courses, such as public foundation, relevant knowledge and professional development, which enable students to comprehensively improve their comprehensive quality and multi-angle scientific thinking methods in terms of basic theory, basic knowledge and related fields, and cultivate students' adaptability and development potential.

The professional curriculum group consists of basic engineering courses, compulsory courses, professional orientation courses and elective courses.

Because of the different professional orientation of the professional basic courses, professional orientation courses are also different, class hours are not the same. Professional basic courses, professional orientation courses in accordance with the requirements of professional direction and knowledge consistency, the need to cross-arrange the course. The professional basic course group mainly consists of "circuit", "module", "digital electricity", "automatic control theory", "microcomputer principle", "power electronics technology", "electrical science", "sensing technology", "engineering mechanics", "electromagnetic field" and other series of courses, So that students can acquire basic knowledge of electrical engineering, and fully consider the broadening of professional caliber in the future, and lay a solid foundation for professional study. Electrical engineering and automation specialty can be divided into electric power system and automation direction, industrial automation direction and transmission line engineering design direction. For example, the course group of power system and its automation direction is mainly composed of compulsory courses and elective courses such as "power system analysis", "power plant main system", "power system relay protection", "power system automatic control", "high voltage technology", etc. The course group of design direction of transmission line engineering is mainly composed of compulsory courses and elective courses such as "engineering measurement", "transmission line design", "power system foundation", "transmission line construction", "mechanical design foundation", "high voltage technology" and so on.

Students need to master not only basic knowledge, but also professional and systematic knowledge through the study of the above series of courses, at the same time, it emphasizes on 
cultivating students' ability to analyze and solve practical problems, so as to make necessary knowledge reserve for cultivating grassroots applied talents.

\section{STRENGTHEN PRACTICAL TEACHING AND CULTIVATE TALENTS WHO ARE ORIENTED TO MARKET DEMAND}

They should not only have theoretical knowledge, but more importantly, strengthen practical teaching, improve computer application ability, engineering practice ability, innovation and entrepreneurship ability, and highlight practical education. The group of practical courses includes: course experiment, course design, on-campus practice (metalworking practice and electrical practice), off-campus practice (cognition practice, production practice and graduation practice) and graduation design. These links play an important role in cultivating students' basic skills and practical skills.

\section{A. Curriculum experiment}

Experimental teaching is a powerful guarantee to cultivate students' practical ability, which to some extent determines the strength of students' ability. Increasing investment in the laboratory, the experimental conditions have been continuously improved. According to the actual situation and the requirements of teaching reform, the experiment teaching of corresponding courses is integrated. In the choice of experimental projects, we changed the traditional experimental teaching is just a verification experiment, retaining the classic necessary experimental projects, deleting those experimental projects that can or cannot be removed, and adding to the remaining experimental projects.

\section{B. Curriculum design}

Curriculum design is an important practical teaching link of students' theory and practice, and it is also a professional training for students. In the talent training program of this major, there are the course design of MCU principle and interface technology and PLC course design in the professional basic course group. There are two courses in the course group of professional orientation, such as power system and its automation direction power system steady state analysis course design and power system transient analysis short-circuit current calculation course design. The purpose of course design is to consolidate and deepen the professional theoretical knowledge learned by students. It can cultivate students' basic skills of design, calculation, drawing, computer application, literature review and report writing.

\section{Student teaching}

In order to improve students' practical ability, practical teaching links such as on-campus practice (metalwork practice and electrician practice), off-campus practice (cognition practice, production practice and graduation practice) are arranged in the professional training program. In order to ensure the consistent implementation of the training program, we have chosen a suitable practice base for our major, and have formulated relevant practice taskbooks and practice instructions. Now we have signed a student practice agreement with 8 units outside the university. Become our outside school practice base. Before each internship, the tutor should write the internship plan, organize the intern mobilization meeting in time, and then the intern tutor should lead the team to practice.

\section{Graduation design (thesis)}

Graduation design (thesis) is mainly to enable students to train in the comprehensive application of professional knowledge, scientific research methods and engineering design skills through graduation design (thesis), to cultivate the ability to analyze and solve scientific problems independently, and to cultivate scientific attitude and innovation consciousness. And the purpose of teamwork spirit. Graduation design is the last link of undergraduate practical teaching, an important training stage to achieve the training goal and requirements, a comprehensive examination of students' knowledge, ability and quality, and the basis for the examination of students' graduation qualification and degree qualification. Graduation project (thesis) is one of the important links in college students' teaching practice.

\section{CONCLUSION}

Electrical engineering and its automation specialty, through scientific orientation, determines the training of high-level applied technical personnel at the grassroots level, which is of practical significance for realizing the training goal of electrical engineering and its automation specialty. Reform the professional curriculum system, improve the quality of personnel training, and promote the construction of personnel training mode in electrical engineering and automation with special professional construction and teaching research projects. Strengthening practical teaching, improving engineering practice ability, innovation and entrepreneurial ability are of guiding significance for improving the quality of running a school and developing its own professional characteristics.

\section{REFERENCES}

[1] Wang Dongying. Research on the Innovation of personnel training Mode of Electrical Engineering and Automation Specialty in Private Universities under the background of mass entrepreneurship and innovation[J].Industry and Technology Forum,2018,17(11):189-190.

[2] Liu Yang, Zheng Wen, Zhong Fei, Zhang Hong. Research on the problems and Strategies of innovative talents training Mode in Electrical Engineering and its Automation Specialty[J].Age agricultural machinery,2018,45(02):193-194+198.

[3] Cai Juan, Zhang Leping, he da. Exploration and practice of Special Features of Electrical Engineering and its Automation Specialty under the training Mode of Applied talents[J].Education and teaching forum,2017(19):121-122.

[4] Wang Jianan, Huang Qi. The Construction of Electrical Engineering and its Automation Specialty and the Exploration of Talent training Model[J].Residential and Real Estate,2016(30):264. 